総説

[環境化学 (Joumal of Environmental Chemistry) Vol. 6, No. 1, pp. 1-15, 1996]

\title{
超臨界流体抽出法を応用した環境試料分析
}

\author{
川本克也 \\ 関東学院大学工学部建築設備工学科 \\ （ ₹236 横浜市金沢区六浦町4834）
}

[平成 7 . 年11月 1 日受理 $]$

\section{Analytical-scale Supercritical Fluid Extraction for the Determination of Pollutants in Environmental Matrices}

\author{
Katsuya KAWAMOTO \\ Dept. of Architectural Environmental Engineering, Faculty \\ of Engineering, Kanto Gakuin University \\ (4834 Mutsuura, Kanazawa-ku, Yokohama 236) \\ [Received November 1, 1995]
}

\begin{abstract}
Summary
The interest in using supercritical fluid extraction (SFE) as a replacement for conventional liquid solvent extraction for organic pollutants from environmental samples has increased rapidly because of need to reduce liquid solvent use as well as to perform more rapid sample preparations. There are many factors such as pressure, temperature, modifier addition etc. in the application of SFE, and are many researches concerning the development of quantitative methods for the recovery of organics. This paper describes the principles of SFE and numerous environmental applications. Further, the characteristics of operational factors and optimization of extraction condition are discussed with reviewing literatures.
\end{abstract}

Key words: supercritical fluid extraction, organic pollutant, solid sample, environmental analysis, optimization

\section{1.はじめに}

近年，化学物質による広範な環境污染とそれによる生 態系への影響が問題化し，土袞や底質あるいは廃棄物な どの固体状試料中に含まれる有機污染物質量を測定する ことが, 污染の状況や環境への影響の予測あるいは化学: 物質に対する処理効果の評価において非常に重要な過程 となってきた。

この含有量測定のための第一段階の操作として一般的 なのは, 従来, 多量の有機溶媒を用いて固液抽出を行い, 対象物質を溶媒相へ移すことである。ところが，ソック スレ一抽出や超音波抽出などの形態をとる溶媒抽出操作 には通常かなりの時間を要し,また有機溶媒そのものに
人体に有害なものが多く，多量の廃溶剤の発生もあるこ となどから，より安全で省資源的であり，短時間に抽出 が呵能な方法が指向されるようになりつつある。

上記の要求を満たし得る抽出技法として, 最近, 超臨 界流体抽出（以下，SFE と略記する。）法が注目されて いる ${ }^{1-4)}$ 。これは，超臨界流体すなわち臨界圧および臨 界温度をともに超えた物理化学的状態下の流体が, 固体 マトリックス中に含まれる溶質分子に対してすぐれた分 離・抽出作用を示すことを利用した抽出法であり，工業 的な分離操作抢よびクロマトグラフィーによる分離・分 析のための試料調製に応用されつつある。

工業的にSFEを用いた例としては，コーヒー豆から のカフェインの抽出や各種植物からの有用成分の抽出な 
どが知られている。試料調製に用いた例としては，植物 体などの生物試料やポリマー中の含有成分，土壌を始め とする環境試料中の種々の有害有機化合物分析のための 前処理への応用例があり，欧米を中心に急速にその数を 増しつつある。一方, 超臨界流体をキャリヤーとした超 臨界流体クロマトグラフィーに関する研究も進行してい $3^{5)}$ 。このような状況を反映して, SFE 装置の開発・改 良がとくに米国で盛んに行われており ${ }^{6)}$ ，EPAにおいて も最近, SFE 法を石油系炭化水素類の公定抽出法の一つ に定める動きがある7”。それは，土壌などからのSFE 抽 出物を少量のテトラクロロエチレンで捕集した後, 赤外 分光法により分析する方法である ${ }^{81}$ 。

このような欧米における注目と普及に比べ，わが国で は，まだSFEに対する認識の度合いも小さく，一般的 な抽出手段にはなっていない。しかし，化学および化学 工学の立場からは, 近年, 超臨界流体のもつ特異な性質 の解明と化学反応への応用を目的として各方面から多様 な研究が行われ，一定の成果が得られている ${ }^{91}$ 。

SFE 法を固体中有害化学物質の測定に応用しようとす るときにここの手法がどのような抽出・分離特性を有し, どこまで実用性があるのかが重大な関心事であると思わ れる。そこで, 本稿では, SFE 法の環境試料分析への応 用を中心に近年の研究例を通して，これらの関心事を明 らかにしていくこととしたい。

\section{2. 超臨界状態と超臨界流体抽出}

\section{1 超臨界状態と超臨界流体}

二酸化炭素（以下, $\mathrm{CO}_{2}$ と表記する。）を始め気体の 圧力を一定温度のもとで上げていくと，圧縮されて体積 が減少し，臨界圧力において液化が始まる。ところが， ある温度以上では気体をどれだけ圧縮しても液化が生じ ず，高密度化するだけである。このような状態を超臨界 状態と呼び, この状態下での流体は, 通常の気体や液体 とはかなり異なった物理化学的特性を示すようになる。

Fig.1は，圧力および温度軸に対する超臨界状態の位置

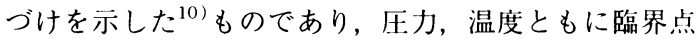
以上の領域が超臨界状態である。

Table 1は, 流体に用いられる代表的な物質の臨界点

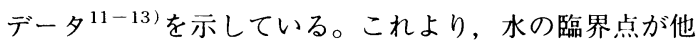
の物質に比較して著しく高いこと，それに対して， $\mathrm{CO}_{2}$ の值がかなり低いことがわかる。とくに, 臨界温度が $31{ }^{\circ} \mathrm{C}$ 程度であることは，熱的に不安定な物質を取り扱う上で たいへん有利となる。SFEのための流体として比較的多 く適用されるのは, $\mathrm{CO}_{2}{ }^{1-3)}$, クロロフルオロカーボ ン14).15), 亜酸化窒素 ${ }^{15)}{ }^{16)}$ などである。なかでも $\mathrm{CO}_{2}$ は, 上記特徵のほか毒性がなく，大気圧下ではガス化するの で廃棄物を生じないこと，しかも安価で純度の高い液化 炭酸ガスが得られる ${ }^{3)}$ などの利点を有することから,
もっとも多く用いられる。その他，少数ではあるが，水 が用いられる例 ${ }^{17)} も$ ある。

超臨界流体が有する特徴のうち有機化合物の抽出に関 連する点としては，1）水や $\mathrm{CO}_{2}$ などの無機化合物で も有機化合物に対する溶解力が格段に高まること，2） 臨界点近傍ではわずかな圧力または温度変化で密度が大 きく変化し, 大きな溶解度差が得られること，3）超臨 界流体は粘性が低く，気体同様の高い搪散速度を示すこ と，などがあげられる。Table 2は，気体，液体および 超臨界流体について, 密度ほか物性值の概略の比較を示 したものである。密度では液体に近く，拡散係数では気 体に近いことが示されている。

超臨界流体の溶媒強度すなわち溶質に対する溶解度 は，流体の密度に直接依存するといわれている(1).31.4)。 このことは, 固体マトリックス中に含有される物質の抽 出能が超臨界流体の密度に依存することを示している。

一般に, 溶液論において正則溶液の溶質溶解度は, 溶解 力を表わす Hildebrandの溶解パラメーター。によって 規定される ${ }^{18)}$ 。液体だけでなく，液体に近い密度を有 する超臨界流体においても，下式に示すようにうを定義 することができる19)。

$$
\delta=1.25 \mathrm{P}_{\mathrm{c}}{ }^{1 / 2}\left\{\rho_{\mathrm{r}} / \rho_{\mathrm{r}}(\mathrm{liq})\right\}
$$

ここで $\mathrm{P}_{\mathrm{c}}$ : 臨界圧力, $\rho_{\mathrm{r}}$ : 超臨界流体の密度, $\rho_{\mathrm{r}}(\mathrm{liq})$ : 液体での密度，である。すなわち， $\rho_{\mathrm{r}}$ が大きくなる

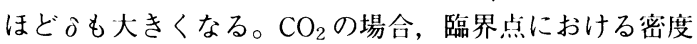
は $0.468 \mathrm{~g} \cdot \mathrm{cm}^{-3}$ であるが, これが圧力および温度の組 み合わせに応じて $1 \mathrm{~g} \cdot \mathrm{cm}^{-3}$ 程度まで大きくなるととも に，溶解度も大きくなると解釈される。しかし，このよ うな関係は抽出対象物が高濃度に含まれる場合には当て

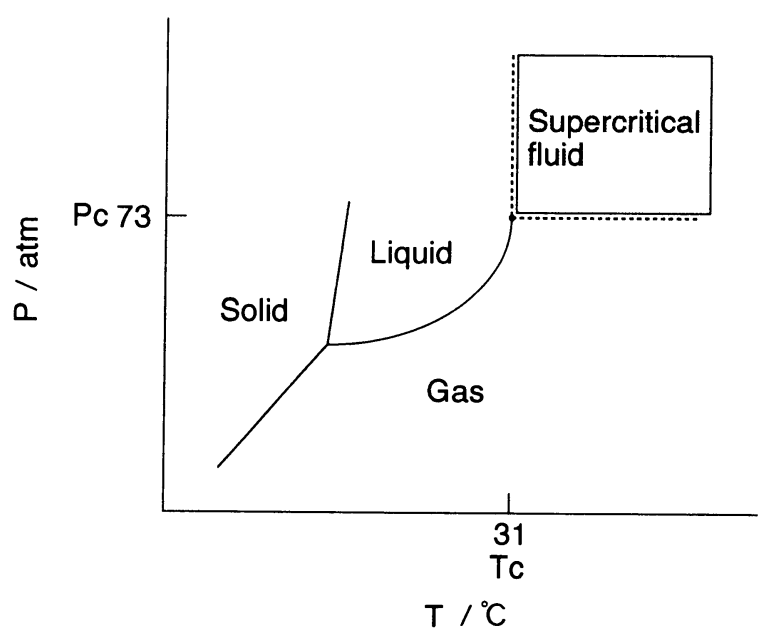

Fig. 1 Phase diagram for carbon dioxide ${ }^{10)}$. 
Table 1 Physico-chemical properties of representative compounds used as supercritical fluid

\begin{tabular}{ccccc}
\hline Compound & $\begin{array}{c}\text { Critical } \\
\text { temperature }(\mathrm{C})\end{array}$ & $\begin{array}{c}\text { Critical pressure } \\
(\mathrm{MPa})\end{array}$ & $\begin{array}{c}\text { Critical density } \\
\left(\mathrm{g} \mathrm{cm}^{-3}\right)\end{array}$ & $\begin{array}{c}\text { Dipole moment } \\
(\mathrm{D})^{\star}\end{array}$ \\
\hline Ethylene & 9.2 & 5.03 & 0.217 & 0 \\
Carbon dioxide & 31.0 & 7.38 & 0.468 & 0 \\
Ethane & 32.2 & 4.88 & 0.203 & 0 \\
Nitrous oxide & 36.5 & 7.23 & 0.457 & 0.161 \\
Propylene & 91.8 & 4.62 & 0.232 & 0.364 \\
Chlorodifluoromethane & 96.1 & 4.97 & 0.524 & 1.4 \\
(Freon 22) & 96.6 & 4.24 & 0.217 & 0.084 \\
Propane & 111.7 & 3.99 & 0.558 & 0.5 \\
Dichlorodifluoromethane & 132.4 & 11.27 & 0.235 & 1.47 \\
(Freon 12) & 234.2 & 2.97 & 0.233 & 0 \\
Ammonia & 239.4 & 8.09 & 0.272 & 1.66 \\
Hexane & 288.9 & 4.89 & 0.302 & 0 \\
Methanol & 318.5 & 4.11 & 0.292 & 0.375 \\
Benzene & 374.1 & 22.0 & 0.322 & 1.85 \\
Toluene & & &
\end{tabular}

${ }^{\star} 1 \mathrm{D}=3.33564 \times 10^{30} \mathrm{Cm}$

Table 2 Approximate values of densities, viscosities and diffusion coefficients of gases, supercritical fluids and liquids ${ }^{3)}$

\begin{tabular}{cccc}
\hline Fluid & Density $\left(\mathrm{g} \cdot \mathrm{cm}^{-3}\right)$ & Viscosity $(\mathrm{Pa} \cdot \mathrm{s})$ & $\begin{array}{c}\text { Diffusion coefficient } \\
\left(\mathrm{cm}^{2} \cdot \mathrm{s}^{-1}\right)\end{array}$ \\
\hline Gas & $(0.6 \sim 2) \times 10^{-3}$ & $(1 \sim 3) \times 10^{-5}$ & $0.1 \sim 1.0$ \\
Supercritical fluid & $0.2 \sim 0.9$ & $(1 \sim 3) \times 10^{-4}$ & $(0.1 \sim 5) \times 10^{-4}$ \\
Liquid & $0.6 \sim 1.6$ & $(0.2 \sim 3) \times 10^{-3}$ & $(0.2 \sim 3) \times 10^{-5}$ \\
\hline
\end{tabular}

はまるが, かなり低濃度の場合が多い実際の環境試料に 対しては当てはまらないともいわれる ${ }^{1)}$ 。抽出が溶解度 のみに依存する場合には単純に上記関係をもとに溶解度 増加に伴う抽出効率の向上を予測すればよいが, 複雑な 試料マトリックスからの抽出には後述するように複数の 影響因子が作用すると考えられる。

\section{2 超臨界流体抽出装置}

分析試料調製のための前処理を目的とした超臨界流体 抽出装置の構成は，Fig.2に例を示すように，55～80
$\mathrm{MPa}(500$ 750atm) 程度までの高圧を得られるポンプと， 抽出対象試料を入れるためのステンレス鋼製または特殊 プラスチック製試料容器を一定温度に保持し, 超臨界流 体の制御用バルブを備えた抽出器，および各ユニットを 電気的に制御するコントローラーから成っている。試料 容器の内部容量は機器メーカーによって異なるが， 0.5 $\sim 20 \mathrm{ml}$ 程度が一般的であり, 容器上下は試料を保持す るとともに超臨界流体が透過可能なフリットで固定す る。2つ以上の試料容器に同時に超臨界流体を送ること のできる装置が一般に市販されている。 


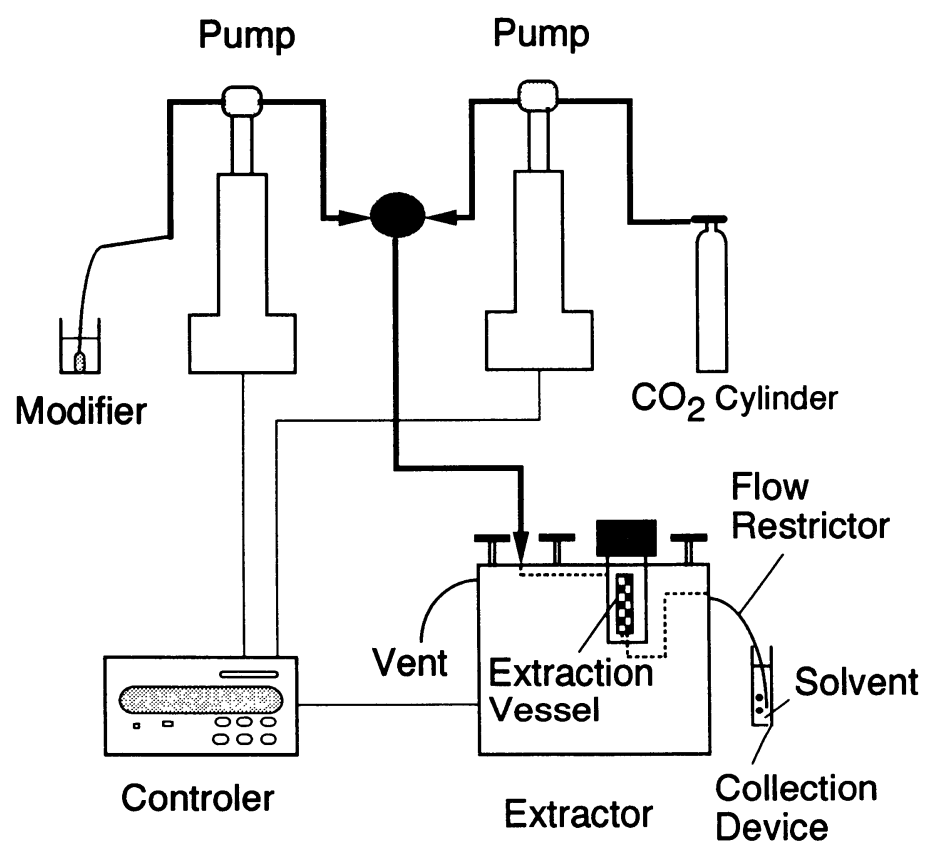

Fig. 2 Composition of SFE instrument.

極性化合物の抽出効率を向上させることを目的とし て, 超臨界流体に少量の極性有機溶媒を添加する抽出方 法があり，この添加溶媒はモディファイヤーまたはエン トレーナー, 調整剤と呼ばれる。モディファイヤーの適 用方法には静的方法と動的方法とがある。静的方法は, 容器内に入れた固体試料に抽出前に有機溶媒を少量添加 する方法であり，動的方法とは，ポンプを 2 台使用し， 抽出器に流体が入る前に超臨界流体とモディファイヤー を混合することで行われる。なお，モディファイヤーを 添加すると, $\mathrm{CO}_{2}$ の臨界圧力および温度の数值がやや上 がることに留意する必要がある。

試料容器から被抽出物とともに流出した超臨界流体 は,リストリクターと呼ばれる内径の極く小さいチュー ブを通して常圧の外部へ放出される。リストリクターに は, 内径 $20 \sim 100 \mu \mathrm{m}$ 程度の溶融シリカガラスキャピラ リー管またはステンレス鋼管が用いられる。

リストリクター先端部を試験管内の少量の有機溶媒中 に挿入することで，抽出物は溶媒に吸収・捕捉される。 これがもっとも一般的な捕集方法であるが,一方,テナッ クスやフロリジル, ODS 固相などのクロマトグラフィー 用充填剤, 固体吸着剂にリストリクターからの抽出物を いったん吸着させることも行われ20).21)，これによると 捕集の確実性が高まる。吸着後溶媒を用いて脱離するこ とになるが,この操作が同時に目的物質のためのクリー ンアップをすることになり22),23)，とくにダイオキシン
類など微量成分を複雑なマトリックスから分離分析する のに有効である。

いずれにしても,このようにSFEと抽出物の検出と が直接的に接続されない抽出モードをオフライン抽出と 呼ぶ。これに対して，適当なインターフェースを設ける ことにより, 各種のクロマトグラフと直接的にオンライ ンで接続することも可能であり,この場合をオンライン 抽出と呼ぶ。

\section{3. オフライン抽出と操作条件}

\section{1 環境固体試料からの有害化学物質の抽出}

SFEによる固体状環境試料中からの有害物質の抽出事 例は, 試料の種類と対象となる物質によって分類するこ とができる。すなわち, 従来の適用例を分類すると, 固 体状環境試料としては土壤, 底質, 都市粉じん, ディー ゼル排ガス粒子, 焼却飛扊, 污泥, さらに生体試料であ る魚類組織, 植物組織, 穀物などが対象となっている。 一方, 物質では, 農薬, PCB やダイオキシン類などの中 · 高沸点有機塩素化合物, 低沸点有機塩素化合物, 多環芳 香族類, 石油系炭化水素類, フタル酸エステル類, 有機 スズ化合物, さらには特殊な化学兵器物質やウランなど の無機化合物への適用例がある。これらの適用例を抽出 条件について整理して示すと Table $3^{7) .15) .24-36) の よ う ~}$ になる。

Table 3より, 超臨界流体として $\mathrm{CO}_{2}$ を用いる例が非 
Table 3 SFE applications of environmental analysis

\begin{tabular}{|c|c|c|c|c|c|c|c|c|c|c|}
\hline \multirow{2}{*}{$\begin{array}{l}\text { Sample } \\
\text { matrix }\end{array}$} & \multirow{2}{*}{ Extracted analy te } & \multicolumn{7}{|c|}{ SFE conditions } & \multirow{2}{*}{$\begin{array}{l}\text { Extraction } \\
\text { efficiency }\end{array}$} & \multirow{2}{*}{$\begin{array}{l}\text { Ref. } \\
\text { No. }\end{array}$} \\
\hline & & Fluid & Press. & Temp. & Modifier & Time & Trapping system & The others & & \\
\hline \multirow{8}{*}{ Soil } & $\begin{array}{l}\text { Petroleum } \\
\text { hydrocarbons }\end{array}$ & $\mathrm{CO}_{2}$ & 340 atm & $80^{\circ} \mathrm{C}$ & Nothing & $30 \mathrm{~min}$ & $\begin{array}{l}\text { Tetrachloroethy- } \\
\text { lene liquid trap }\end{array}$ & $\begin{array}{c}\text { Flow rate : } 1 \\
\sim 2 \mathrm{ml} / \mathrm{min}\end{array}$ & $>80 \%$ & 7 \\
\hline & $P C B$ & $\mathrm{CO}_{2}$ & $20 \mathrm{MPa}$ & $50^{\circ} \mathrm{C}$ & Nothing & $\begin{array}{l}10 \text { min static } \rightarrow \\
20 \text { min dynamic }\end{array}$ & $\begin{array}{l}\text { sooctane liquid } \\
\text { trap }\end{array}$ & & $\begin{array}{c}85 \sim 105 \\
\%\end{array}$ & 24 \\
\hline & Chlorophenols & $\mathrm{CO}_{2}$ & $37.2 \mathrm{MPa}$ & $80^{\circ} \mathrm{C}$ & Nothing & $\begin{array}{l}5 \mathrm{~min} \text { static } \rightarrow \\
5 \mathrm{~min} \text { dynamic }\end{array}$ & $\begin{array}{c}\text { ODS Solid-phase } \\
\text { trap }\end{array}$ & $\begin{array}{l}\text { Acetyl } \\
\text { derivatized }\end{array}$ & $\begin{array}{l}\text { Satis- } \\
\text { factorily }\end{array}$ & 25 \\
\hline & $\begin{array}{l}\text { Pesticides (47 Organo- } \\
\text { phosphoruses and } 41 \\
\text { organochlorines) }\end{array}$ & $\mathrm{CO}_{2}$ & $\begin{array}{c}150 \sim \\
350 \text { atm }\end{array}$ & $50 \sim 70^{\circ} \mathrm{C}$ & $\begin{array}{c}\text { Methanol } \\
\text { (dynamic, static) }\end{array}$ & $30,60 \mathrm{~min}$ & $\begin{array}{l}\text { n-Hexane, Di- } \\
\text { chloromethane, } \\
\text { Methanol liquid } \\
\text { trap }\end{array}$ & $\begin{array}{l}2.0,4.7 \mathrm{ml} \\
\text { Vessel; } 1.0, \\
2.5 \mathrm{~g} \text { Sample }\end{array}$ & $>75 \%$ & 26 \\
\hline & PAH & $\begin{array}{l}\mathrm{CHClF}_{2} \\
\mathrm{~N}_{2} \mathrm{O}, \mathrm{CO}_{2}\end{array}$ & $\begin{array}{c}62 \sim 400 \\
\text { at } m\end{array}$ & $\begin{array}{c}50 \sim 100 \\
{ }^{\circ} \mathrm{C}\end{array}$ & $\begin{array}{c}\text { Methanol } \\
\text { (dynamic,with } \\
\mathrm{CO}_{2} \text { ) }\end{array}$ & $\sim 40 \mathrm{~min}$ & $\begin{array}{l}\text { Dichloromethane } \\
\text { liquid trap }\end{array}$ & $\begin{array}{l}\text { Flow rate : } \\
0.5 \sim 0.8 \\
\mathrm{ml} / \mathrm{min}\end{array}$ & $\begin{array}{l}\mathrm{CHClF}_{2} \text { is } \\
\text { the best } \\
\text { fluid. }\end{array}$ & 15 \\
\hline & Diesel fuel & $\mathrm{CO}_{2}$ & $290 \mathrm{~atm}$ & $23 \sim 25^{\circ} \mathrm{C}$ & Nothing & $10 \mathrm{~min}$ & Dichloromethane & Subcritical & $>90 \%$ & 27 \\
\hline & $\begin{array}{l}\text { Chemical warfare agent } \\
\text { simulants }\end{array}$ & $\mathrm{CO}_{2}$ & 300 atm & $60{ }^{\circ} \mathrm{C}$ & $\begin{array}{l}\text { Nothing or } \\
\text { methanol } \\
\text { (dynamic) }\end{array}$ & $5,12 \mathrm{~min}$ & $\begin{array}{l}\text { Methanol liquid } \\
\text { trap }\end{array}$ & $\begin{array}{l}2 \text { ppm } \\
\text { spiked }\end{array}$ & $79 \sim 95 \%$ & 28 \\
\hline & $\begin{array}{l}\text { Organotin } \\
\text { compounds }\end{array}$ & $\mathrm{CO}_{2}$ & $\begin{array}{l}100 \text { or } \\
350 \text { atm }\end{array}$ & $\begin{array}{c}40 \text { or } 80 \\
{ }^{\circ} \mathrm{C}\end{array}$ & $\begin{array}{l}\text { Nothing or } 5 \% \\
\text { methanol } \\
\text { (dynamic) }\end{array}$ & $10,40 \mathrm{~min}$ & $\begin{array}{l}\text { n-Hexane liquid } \\
\text { trap }\end{array}$ & $\begin{array}{l}\text { Chelating } \\
\text { agent is } \\
\text { added. }\end{array}$ & $\begin{array}{l}\text { Tetraalkyl: } \\
90-110 \% \\
\text { lonic: } 50- \\
75 \%\end{array}$ & 29 \\
\hline Sediment & s-Triazine herbicides & $\mathrm{CO}_{2}$ & 230 bar & $48^{\circ} \mathrm{C}$ & $\begin{array}{l}\text { Methanol } \\
\text { (static) }\end{array}$ & $30 \mathrm{~min}$ & $\begin{array}{l}\text { Methanol liquid } \\
\text { trap }\end{array}$ & $\begin{array}{l}0.57 \mathrm{ml} \mathrm{Ve}- \\
\text { ssel : } 0.5 \mathrm{~g} \\
\text { Sample }\end{array}$ & $\begin{array}{l}\text { Simazine: } \\
93-103 \%\end{array}$ & 30 \\
\hline
\end{tabular}

Table 3 SFE applications of environmental analysis (continued)

\begin{tabular}{|c|c|c|c|c|c|c|c|c|c|c|}
\hline \multirow{2}{*}{$\begin{array}{l}\text { Sample } \\
\text { matrix }\end{array}$} & \multirow[b]{2}{*}{ Extracted analy te } & \multicolumn{7}{|c|}{ SFE condition } & \multirow{2}{*}{$\begin{array}{l}\text { Extraction } \\
\text { efficiency }\end{array}$} & \multirow{2}{*}{$\begin{array}{l}\text { Ref } \\
\text { No }\end{array}$} \\
\hline & & Fluid & Press. & Temp. & Modifier & Time & $\begin{array}{c}\text { Trapping } \\
\text { system }\end{array}$ & The others & & \\
\hline $\begin{array}{l}\text { Soil and } \\
\text { sediment }\end{array}$ & $\begin{array}{l}12 \text { Pesticides (organo- } \\
\text { phosphate and } \\
\text { organochlorine) }\end{array}$ & $\mathrm{CO}_{2}$ & 350 atm & $50^{\circ} \mathrm{C}$ & $3 \%$ Methanol & $\begin{array}{l}10 \text { min static } \rightarrow \\
20 \text { or } 40 \mathrm{~min} \\
\text { dynamic }\end{array}$ & $\begin{array}{l}\text { Methyl tert- } \\
\text { butyl ethel } \\
\text { liquid trap }\end{array}$ & $\begin{array}{l}\text { Vessel : } 2 \text { or } \\
10 \mathrm{ml}\end{array}$ & $>85 \%$ & 31 \\
\hline $\begin{array}{l}\text { Diesel ex- } \\
\text { haust parti- } \\
\text { culate matter }\end{array}$ & PAH, nitro-PAH & $\begin{array}{c}\mathrm{CO}_{2 .} \\
\text { Freon22 }\end{array}$ & $400 \mathrm{~atm}$ & $\begin{array}{c}40 \sim 100 \\
{ }^{\circ} \mathrm{C}\end{array}$ & $\begin{array}{l}\text { Methanol, } \\
\text { Freon22, } \\
\text { Toluene }\end{array}$ & $30 \mathrm{~min}$ & $\begin{array}{l}\text { Dichlorome- } \\
\text { thane liquid } \\
\text { trap }\end{array}$ & $\begin{array}{l}\text { Flow rate : } \\
\text { ca. } 0.3 \\
\text { mVmin }\end{array}$ & $\begin{array}{l}\text { Freon22 and } \\
\mathrm{CO}_{2}+\text { toluene } \\
\text { are effective to } \\
\text { nitropylene. }\end{array}$ & 32 \\
\hline \multirow{2}{*}{ Fly ash } & Dioxins & $\mathrm{CO}_{2}, \mathrm{~N}_{2} \mathrm{O}$ & 400 atm & $\begin{array}{l}40^{\circ} \mathrm{C} \\
60^{\circ} \mathrm{C}\end{array}$ & $\begin{array}{l}10 \% \text { Benzene } \\
\text { or toluene }\end{array}$ & $2 \mathrm{~h}$ & $\begin{array}{l}\mathrm{n} \text {-Hexane } \\
\text { liquid trap }\end{array}$ & $\begin{array}{l}\text { Acid treat- } \\
\text { ment is also } \\
\text { performed. }\end{array}$ & $\begin{array}{l}\text { Benzene } \\
\text { modifier or acid } \\
\text { treatment is } \\
\text { effective. }\end{array}$ & 33 \\
\hline & Chlorobenzenes & $\mathrm{CO}_{2}$ & $\begin{array}{c}10 \sim 50 \\
\mathrm{MPa}\end{array}$ & $\begin{array}{c}50 \sim 140 \\
{ }^{\circ} \mathrm{C}\end{array}$ & $\begin{array}{l}\text { Nothing or } 5 \% \\
\text { methanol, etha- } \\
\text { nol, aceton and } \\
\text { toluene }\end{array}$ & $1 \mathrm{~h}$ & $\begin{array}{l}\text { n-Hexane } \\
\text { liquid trap }\end{array}$ & $\begin{array}{l}\text { Acid treat- } \\
\text { ment is also } \\
\text { performed. }\end{array}$ & $\begin{array}{l}\text { Increasing } \\
\text { temperature is } \\
\text { relatively } \\
\text { effective. }\end{array}$ & 34 \\
\hline $\begin{array}{l}\text { Sewage } \\
\text { sludge }\end{array}$ & $\begin{array}{l}\text { Anionic surfactants } \\
\text { (SAS, LAS) }\end{array}$ & $\mathrm{CO}_{2}$ & $400 \mathrm{~atm}$ & $80^{\circ} \mathrm{C}$ & Nothing & $\begin{array}{l}5 \text { min static } \\
\rightarrow 10 \quad \mathrm{~min} \\
\text { dynamic }\end{array}$ & $\begin{array}{l}\text { Chloroform } \\
\text { liquid trap }\end{array}$ & $\begin{array}{l}\text { lon pair } \\
\text { reagent is } \\
\text { used. }\end{array}$ & ca. $100 \%$ & 35 \\
\hline Fish tissue & PCB & $\mathrm{CO}_{2}$ & 350 at m & $150^{\circ} \mathrm{C}$ & Methanol & $\begin{array}{l}10 \text { min static } \\
\rightarrow 30 \mathrm{~min} \\
\text { dynamic }\end{array}$ & $\begin{array}{l}\text { Solid-phase } \\
\text { trap }\end{array}$ & $\begin{array}{c}\text { Flow rate: } \\
3 \mathrm{ml} / \mathrm{min}\end{array}$ & $\begin{array}{l}\mathrm{CO}_{2} \text { is more } \\
\text { effective. }\end{array}$ & 36 \\
\hline
\end{tabular}


常に多いことが確認される。スーパーファンドサイトに 関連した污染土壤への適用例がもっとも多く, 抽出の操 作条件としてまず圧力は60～480atmの範用で適用され ているが，なかでも200～350atm で設定される場合が多

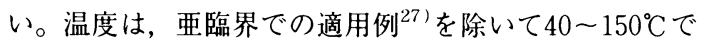

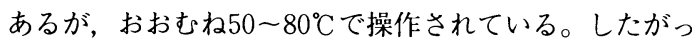
て, これらの圧力と温度条件で決定される超臨界 $\mathrm{CO}_{2}$ の密度は0.6〜0.9g $\cdot \mathrm{cm}^{-3}$ となる。Fig.3に三次元的に 示す ${ }^{37)}$ ように, 低圧／高温から高压／低温条件に向かっ て密度は大きくなる。

モディファイヤーの添加に関する方法は様々である が，メタノールを添加する場合が比較的多く，他にトル エンやアセトンを添加する例もみられる。抽出時間に関 しては, 通常 1 時間以内で設定され, なかでも30分以内 とする例が多い。抽出時間のもつ意味は超臨界流体の流 量および抽出容器の内部容積と密接に関連し, ポンプ出 口で測定された流量が $1 \mathrm{ml} \cdot \mathrm{min}^{-1}$ 前後であれば，内部 容積 $10 \mathrm{ml}$ の比較的大きな容器でも抽出を 30 分間行えば 容積の 3 倍程度の流体を流したことになる。

抽出物質の捕集方法は, 少量の有機溶媒を用いて行う 場合が多く，石油系炭化水素を対象として赤外分光法に よって定量する例 ${ }^{7)}$ を除いてへキサン, 塩化メチレン, メタノールなどガスクロマトグラフィーおよび高速液体 クロマトグラフィーによる分析を前提にした溶媒の選択 が行われる。

以上の各条件による SFEの効率は, 土壌からの場合 はおおむね良好と報告されているが，底質や粒子状物質 あるいは飛灰では， $\mathrm{CO}_{2}$ のみでは不十分であった

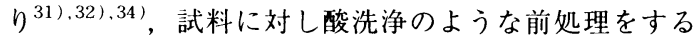

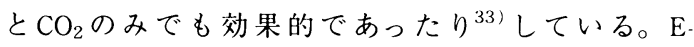
Tilotta ${ }^{38)}$ は, 土壤からの石油系炭化水素の抽出を例

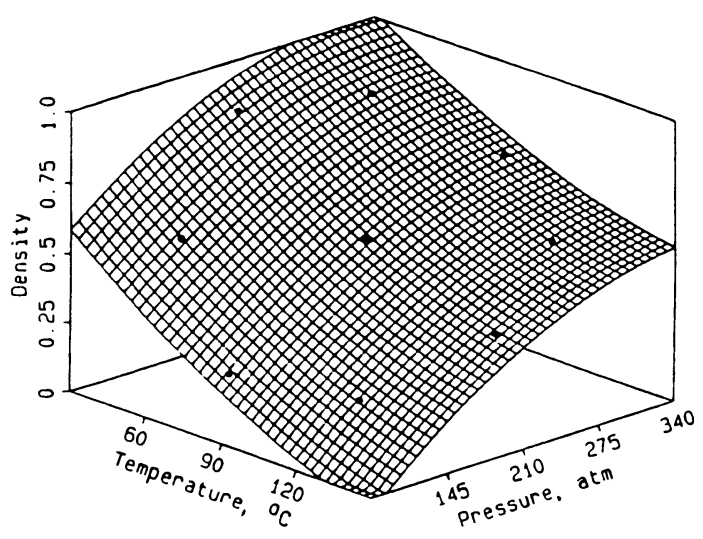

Fig. 3 Density as a function of temperature and pressure $^{37 \text { ) }}$.
に, 流体 $\mathrm{CO}_{2}, 40 \mathrm{MPa}, 150^{\circ} \mathrm{C}$ の条件での $\mathrm{SFE}$ とソック スレー抽出との比較を行い, 灯油成分に関し両者は同程 度の值となり，ベンゼン，トルエンなどの揮発性化合物 の抽出についてはSFEの方がすぐれていると報告して いる。

\section{2 固体吸着剮からの抽出}

SFE 法は環境試料からの抽出だけでなく，水や空気を 採取することで有機物が吸着された固相抽出剤や各種固 体吸着剂からの抽出にも適用される。Table $4^{39-43)} に$ その適用例を示す。

Table 4より, 環境化学物質の捕集に汎用される大部 分の吸着剤への適用が検討されていることがわかる。抽 出効率も一部の物質を除いて良好である。試料マトリッ クスの中でとくにディスク型固相は, 大きな通水速度が 得られて水中有機化合物の捕集・濃縮に有利なだけでな く，ろ紙と同じ形状であり取り扱いが容易であることか ら，超臨界流体抽出装置への適用を図りやすいといえ $ろ^{44)}$ 。また,このような吸着剤の場合には，有機化合 物が比較的弱い疎水結合によって吸着剤表面に吸着され ているために, 超臨界流体による抽出が土壤などの組成 の複雑な環境試料に比較して容易であると考えられる。

\section{3 水からの直接抽出}

水中から超臨界流体への直接抽出に関しては, 主とし て装置上の制約からその例は非常に少ないものの若干の 試みもみられる。それは超臨界 $\mathrm{CO}_{2}$ が試料水中を通ガ スするのと同じ方式で，水中含有成分を溶解させ抽出し ようとする方法である ${ }^{45)}$ 。ただし，この方式では，水 量を大きくすることで濃縮倍率を高くすることがむずか しい。そこで，水層を連続流とすることも考えられ，污 染水の处理への応用という観点から検討されている ${ }^{46)}$ 。

\section{SFEの最適化}

\section{1 抽出効率に対する影暃因子}

SFE 法の特徽の一つは, 压力などの操作因子の変化が 抽出能力の大きな変化につながることであった。した がって, 操作因子条件の選定が非常に重要な意味を持ち, 逆に，どのような条件を設走するかが対象物質の抽出効 率を左右することになる。しかも，多くの因子があるこ とから，条件選択はしばしば経験的になる。

抽出能に影響する装置側の因子には, 压力, 温度, 流 速, 時間, モディファイヤー, 抽出物の捕集方法, 抽出 容器の寸法, 超臨界流体の種類および抽出モードが静的 か動的かなどがある。一方, 適用する固体試料の側から は, 試料の物理化学的性状や試料に対する前処理の有無 があげられる。これらの中で，何を超臨界流体に用いる かに関しては, 安全性や環境への影響を考慮して $\mathrm{CO}_{2}$ 
Table 4 SFE applications of solid adsorbent used for air and water sampling

\begin{tabular}{|c|c|c|c|c|c|c|c|c|c|c|}
\hline \multirow[b]{2}{*}{ Sample matrix } & \multirow[b]{2}{*}{ Extracted analy te } & \multicolumn{7}{|c|}{ SFE condition } & \multirow{2}{*}{$\begin{array}{l}\text { Extraction } \\
\text { efficiency }\end{array}$} & \multirow{2}{*}{$\begin{array}{l}\text { Ref } \\
\text { No. }\end{array}$} \\
\hline & & Fluid & Pressure & $\begin{array}{l}\text { tem- } \\
\text { perature }\end{array}$ & Modifier & $\begin{array}{c}\text { Extraction } \\
\text { time }\end{array}$ & $\begin{array}{c}\text { Collection } \\
\text { method }\end{array}$ & $\begin{array}{c}\text { The } \\
\text { otheres }\end{array}$ & & \\
\hline polyurethane foam & $\begin{array}{l}\text { PCB, PAH, n-Alkane } \\
\left(C_{12} \sim C_{24}\right)\end{array}$ & $\mathrm{CO}_{2}$ & 380 atm & $45^{\circ} \mathrm{C}$ & Nothing & $10 \sim 20 \mathrm{~min}$ & $\begin{array}{l}\text { Dichlorome- } \\
\text { thane liquid } \\
\text { trap or direct } \\
\text { coupling } \\
\text { with GC }\end{array}$ & $\begin{array}{l}\text { Flow rate } \\
: \text { ca } 1 \\
\mathrm{ml} / \mathrm{min}\end{array}$ & $>95 \%$ & 39 \\
\hline $\begin{array}{l}\text { Tenax, Carbopack C, } \\
\text { Florisil, } C_{18} \text { sorbent etc. }\end{array}$ & $P C B, n$-Alkane & $\mathrm{CO}_{2}$ & $20 \mathrm{MPa}$ & $50^{\circ} \mathrm{C}$ & Nothing & $10 \sim 16 \mathrm{~min}$ & $\begin{array}{l}\text { direct } \\
\text { coupling } \\
\text { with GC }\end{array}$ & & $\begin{array}{c}\text { РCB : } 93 \sim \\
105 \%\end{array}$ & 40 \\
\hline $\begin{array}{l}\text { Charcoal, Carbosieve } \\
\text { SII, Chromosorb } 102 \text {, } \\
\text { Tenax-TA, XAD-4 }\end{array}$ & $\begin{array}{l}\text { Dichloromethane, } \\
\text { Ethylene dibromide(EDB), } \\
\text { 4-Nitrobiphenyl, 2-Nitro- } \\
\text { fluorene, Fluoranthene }\end{array}$ & $\mathrm{CO}_{2}$ & $\begin{array}{l}2000 \sim \\
6000 \mathrm{psi}\end{array}$ & $50^{\circ} \mathrm{C}$ & $\begin{array}{l}\text { Methanol, } \\
\text { Acetone, } \\
\text { Ethyl acetate, } \\
\text { n-hexane }\end{array}$ & $15 \sim 210 \mathrm{~min}$ & $\begin{array}{l}\text { Methanol or } \\
\text { toluene liquid } \\
\text { trap }\end{array}$ & $\begin{array}{ll}2 & \mathrm{ml} \\
\text { Vessel }\end{array}$ & $\begin{array}{l}\text { EDB : }>90 \%, \\
\text { Aromatics : } 60 \sim \\
92 \%\end{array}$ & 41 \\
\hline $\begin{array}{l}\text { ODS(disktype), Florisil, } \\
\text { Tenax-GC, XAD-4 }\end{array}$ & $\begin{array}{l}\text { Pesticides ( Diazinon, } \\
\text { Aldrin etc.), Phtalate } \\
\text { esters }\end{array}$ & $\mathrm{CO}_{2}$ & $\begin{array}{l}5000 \sim \\
10000 \mathrm{psi}\end{array}$ & & $\begin{array}{l}5 \% \text { Aceto- } \\
\text { nitrile, } 10 \% \\
\text { methanol }\end{array}$ & & $\begin{array}{l}\text { Methanol } \\
\text { liquid trap }\end{array}$ & & $\begin{array}{l}\text { Pesticides: av. } \\
88 \%, \text { Phtalate } \\
\text { esters : av. } 95 \%\end{array}$ & 42 \\
\hline $\begin{array}{l}\text { Celite, } C_{8} \text { Solid-phase } \\
\text { (disk type) }\end{array}$ & Sulfonyl urea herbicide & $\mathrm{CO}_{2}$ & 350 bar & $50^{\circ} \mathrm{C}$ & $\begin{array}{l}2 \quad \% \\
\text { Methanol }\end{array}$ & $\begin{array}{l}2 \text { min static } \\
\rightarrow 24 \mathrm{~min} \\
\text { dynamic }\end{array}$ & $\begin{array}{l}\text { Solid-phase } \\
\text { trapp with } \mathrm{C}_{18} \\
\text { particles and } \\
\text { stainless- } \\
\text { steel beads }\end{array}$ & $\begin{array}{l}\text { Desorbed } \\
\text { with acto- } \\
\text { nitril, Flow } \\
\text { rate : } 2 \\
\mathrm{ml} / \mathrm{min}\end{array}$ & $\begin{array}{c}61.7 \sim 89.8 \% \\
\left(\mathrm{C}_{8} \text { Solid-phase }\right)\end{array}$ & 43 \\
\hline
\end{tabular}

を用いるのがもっとも妥当な選択であると思われる。し かし，流体を一つに固定しても他に多くの因子がある。 それぞれの因子がもつ影響特性をよく理解することがま ず重要である。

\section{2 圧力の影䈏}

圧力はSFEの多くの操作因子の中で, もっとも大き な影響を与えるものとされている3(26).47)。それは, 抽 出能が溶質の溶解度によって第一に決定され, しかも溶 解度は压力と温度で決定される流体密度に依存するから である。

一定温度の下で压力を増していくと, それに伴い超臨 界流体の密度が高まる。したがって, 圧力の増加が溶解 度および抽出効率の増加につながると解釈できるのであ る。事実, Fig. $4^{3)}$ に例を示すように, 超臨界 $\mathrm{CO}_{2}$ 中に おけるナフタレンの溶解度は圧力増加に依存して高くな る。ここで, $\mathrm{CO}_{2}$ の臨界圧である7.38MPaすなわち約 $75 \mathrm{bar}$ を超え, $\mathrm{CO}_{2}$ が超臨界流体になると急激に溶解度 が大きくなることが示される。

種々の固体 - 環境試料からの有機污染物質の抽出特性 をみると午、24).48).49), この圧力（密度）依存傾向は概 略当てはまる。しかし, 压力がある程度まで高くなると, 溶質に働く斥力のために溶解度が逆にやや小さくなる現 象も現れる4）。超臨界領域の中でも低圧側で圧力上昇の 効果がより大きく現れることになる。さらにこれに加え， 実際の試料では, 圧力以外の要因が非常に大きく作用す る場合があり，高圧化すれば抽出効率が直接的に向上す るとは言えない場合も多い。

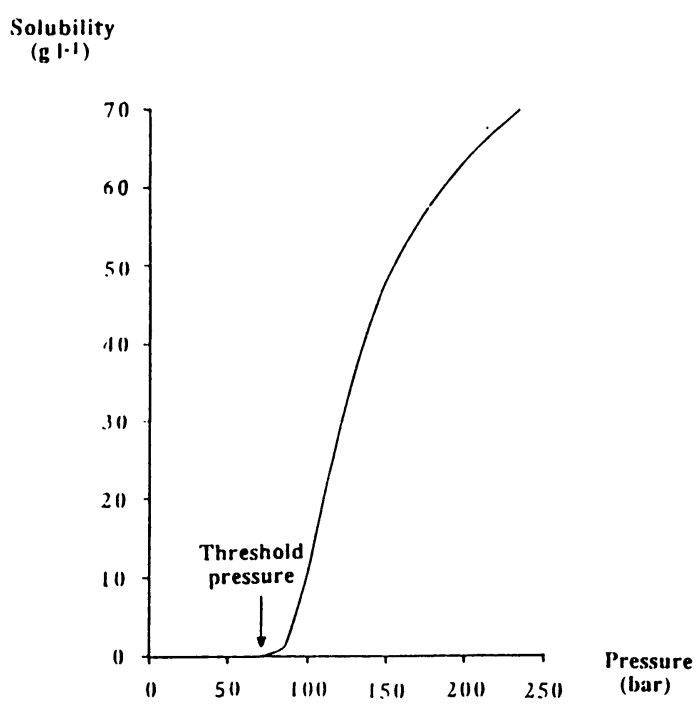

Fig. 4 Variation of the solubility of naphthalene with the pressure of supercritical $\mathrm{CO}_{2}$ at $45^{\circ} \mathrm{C}^{3)}$.

\section{3 温度の影第}

温度は主要な影響因子でないという実験結果も出され ている26) が, 圧力を一定にすれば流体密度は温度に依 存することになるので, 圧力と温度のもつ影響度はその 意味で同じである。圧力一定時の温度影響に関しては, 低温であるほど密度が高くなる。通常 SFEを行おうと 
する場合, 対象物質の熱的な安定性を考慮してか $100^{\circ} \mathrm{C}$ 以上で操作されることは少なく, また抽出装置自体に抽 出容器部の温度をあまり高くできないという制約のある 場合もあって，圧力操作が主体になる場合が多い。それ でも温度による影響は小さいとする報告例があるのは， 圧力と温度の組み合わせを種々変えることによって密度 を一定にして抽出を行っても，抽出効率への温度影響が みられなかった場合である。ダイアジノンやパラチオン などの有機リン系農薬とDDT やエンドリンなどの有機 塩素系農薬を対象として,このような結果が報告されて (る ${ }^{46)}$ 。

一方, 密度一定下の抽出であっても温度の影響が明瞭 に現れてくる場合がある。それは, 対象物質に比較的揮 発性のある場合である。さらに, 高温化が単に物質の揮 発を促進するだけでなく，固体マトリックスからの物質 の脱離に必要な活性化エネルギーを乗り越えさせること にも効果があるという考察がある ${ }^{50)}$ 。Fig.5には, アト ラジン，シマジンなどs-トリアジン系農薬を添加した 底質からの抽出回収率の温度依存性の例を示す。 Langenfeld $ら^{51)}$ は, PCB を含む底質, 多環芳香族類を
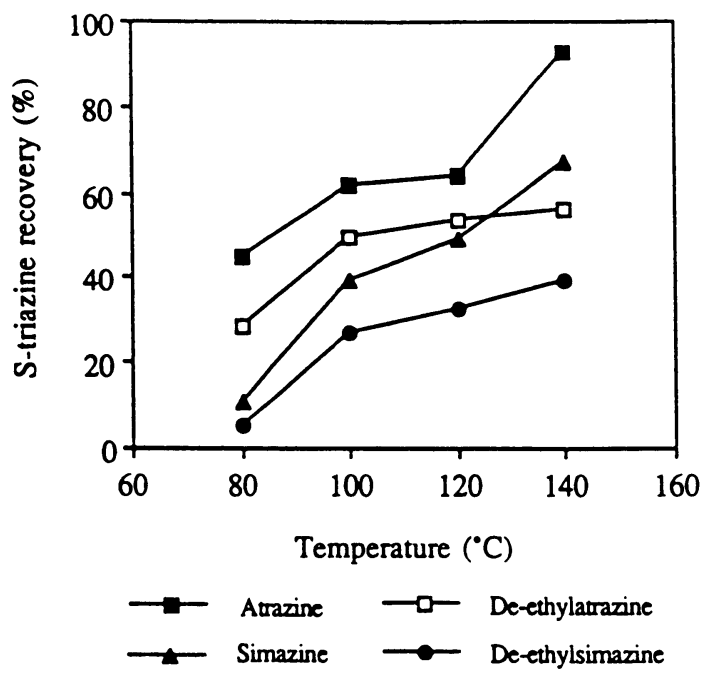

Fig. 5 Effect of extraction temperature on $\mathrm{s}$ triazine recovery from spiked sediment using SFE with unmodified carbon dioxide. Experimental conditions: static extraction, 10 min; dynamic extraction, $30 \mathrm{~min}$; $\mathrm{CO}_{2}$ density, $0.71 \mathrm{~g} \cdot \mathrm{cm}^{-3} ; \mathrm{CO}_{2}$ flow rate, $2 \mathrm{~cm}^{3}$. $\min ^{-1}$; extraction vessel volume, $1 \mathrm{~cm}^{3}$; restrictor temperature $50^{\circ} \mathrm{C}$; collection temperature $50^{\circ} \mathrm{C}$; desorption temperature $30^{\circ} \mathrm{C}$; wash solvent, $4 \mathrm{~cm}^{3}$ acetone at $1 \mathrm{~cm}^{3} \cdot \min ^{-1}$; number of extraction, $3^{50)}$.
含む粉じんおよび土壤を対象に, $\mathrm{CO}_{2}$ のみで $50^{\circ} \mathrm{C}$ と $200^{\circ} \mathrm{C}$ で抽出を行った。その結果, $200^{\circ} \mathrm{C}$ 条件において, ソッ クスレー抽出を用いた含有濃度保証值と同等以上の濃度 測定值が得られたと報告している。

以上より, 温度条件の選定に際しては, 抽出したい物 質の熱安定性や沸点を考慮した上で，高温操作で抽出効 率の向上が予想されるときは他の因子より優先的に行う 方がよいと思われる。

\section{4 モディファイヤーの影霎}

SFEによる有機化合物の抽出において，分子の有する 極性が溶解度に関連した因子として物性上重要である。 Table 1に示すように, 超臨界 $\mathrm{CO}_{2}$ の双極子モーメント は0 Dすなわち無極性である。したがって, 溶質と溶媒 の極性が一致している方が溶解しやすいという経験則か らすると，無極性物質の抽出には $\mathrm{CO}_{2}$ だけで有効であ るが，極性をもつ物質の抽出には必ずしも有利でないと 予想される。そこで, 極性を有する有機溶媒がモディファ イヤーとして $\mathrm{CO}_{2}$ に添加されるのであるが, 流体に極 性をもたせるという意味では, 極性を有するクロロフル オロカーボンにする方法もある15)。

しかし， $\mathrm{CO}_{2}$ の使用を前提にモディファイヤーを考え て選定すると, 水素結合を形成し得る物質が適当である。 従来, もっとも多く用いられるのは双極子モーメント $1.66 \mathrm{D}$ のメタノールであり, これによる抽出効率の向 上を報告している例は非常に多(2)、4),6),42),43),52),53)。 メ夕ノール以外でよく用いられるモディファイヤーに は, トルエン ${ }^{32)}$, エ夕ノール ${ }^{34) .54), ~ ア セ ト ン 411.55), ~}$ アセトニトリル ${ }^{42)}$ などがある。単一物質でなく, 湖や 港湾の底質からの多環芳香族類の抽出のために水, メ夕 ノール, ジクロロメタンの 3 種類を混合してモディファ イヤーとした例もある ${ }^{56)}$ 。 Langenfeld ${ }^{57)}$ は, 河川底質 中の $\mathrm{PCB}$ および都市大気浮遊粒子状物質中の多環芳香 族類抽出に関して, 超臨界 $\mathrm{CO}_{2}$ に対しメタノール, ト ルエン,アセトニトリルなどの通常の溶椷のほかに酢酸 あるいはアニリンといった酸または塩基の適用をも検討 している。添加濃度 $1 \%$ および10\%で添加量の影響も合 わせて検討した結果, 彼らは, モディファイヤー濃度よ りも何をモディファイヤーにするかということの方が抽 出にとって重要であると結論づけた年)。しかしなお， モディファイヤー選択の一般的な原則については, 試料 マトリックスの特性と抽出対象物質を考慮した上でとい う段階にとどまっている。

モディファイヤー添加がなぜ抽出性の向上に効果があ るのかという機構的な検討が, Fahmy ら ${ }^{58)}$ によって行 われている。彼らは, 植物の葉と粘土鈗物に超臨界 $\mathrm{CO}_{2}$ が作用する状況を耐高圧サファイヤガラスを通して観察 したところ，マトリックスの膨潤現象を認めた。膨潤に 
よって広がったマトリックスの間隙に超臨界 $\mathrm{CO}_{2}$ が進 入しやすくなって抽出能が向上すると考えられる。こう して有機物分子とマトリックスとの複合体と超臨界流体 とが相互作用することで有機物分子の脱離をはやめるこ $と^{57)}$ ，また有機物の溶解度を高めることが寄与するも のと思われる。

\section{5 流速の影䇾}

SFE は流通型の溶出操作とみなすことができるので, 流速の小さい方が接触時間を長くとることができて有利 となる。しかし，あまり流速を小さくすると SFEの利 点である短時間での抽出という面が生かせなくなる。逆 に流速を大きくすると，抽出物を溶媒で捕集する際の損 失を招き，また通ガス操作自体に流速上限度がある。最 適な流速値として, 压縮液体 $\mathrm{CO}_{2}$ の流量で $1 \mathrm{ml} \cdot \mathrm{min}^{-1}$ とされることが多(3).34!。この值は，圧力が大気压に もどってガス化したときの流量で約 $500 \mathrm{ml} \cdot \mathrm{min}^{-1}$ に相 当する。

流速はバルブの開閉度によって制御できるが, リスト リクターの内径がおよそ50 $\mu \mathrm{m}$ 以下の場合には, 試料か らの水分または $\mathrm{CO}_{2}$ がドライアイス化することによっ て詰まりを生じ，流速の低下を招くことがあるので注意 が必要である。リストリクターを外部から加熱すること で,このような問題の発生を防ぐ装置が市販されている。

なお, 流速に関連して, 超臨界流体を試料容器の内容

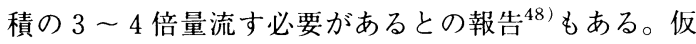
に内容積を $10 \mathrm{ml}$ とすると, $30 \sim 40 \mathrm{ml}$ となり, 流速 $1 \mathrm{ml}$ ならば30４0分間抽出すればよいということになる。

\section{6 その他の因子の影䇺}

試料容器のディメンジョンすなわち内径と高さの比が 抽出効率に影響するという指摘がある ${ }^{3)}$ 。容器断面積が 大きいほど流体の線流速が小さくなるために, 流体とマ トリックスとの接触時間が大きくり, 抽出率の増大に寄 与すると考えられる。しかし一方で, 内径の小さい方が 固体内部での超臨界流体の乱流化を促進することにな り, 抽出率增大に寄与するとの解釈も成り立つ3)。通常 用いられる試料容器の高さは, 内径の数倍から10倍程度 である。ただし，含有濃度が非常に微量であるときは， なるべく多量の試料を必要とし, 容積の小さい容器は使 えないなどの実際面での制約がある。

抽出時の超臨界流体の作用のさせ方に, 試料容器に流 体を流しながら同時に出口側バルブを開けて抽出物を捕 集する方法，および式料容器出口側のバルブを閉じた状 態で流体と試料とを接触させるオう法の 2 者がある。前者 を動的抽出法, 後者を静的抽出法という。全体の抽出時 間が同じでもその一部を静的法で行うことが抽出効率の 向上に寄与するとの報告がある ${ }^{201.54)}$ が, 静的抽出法は
必ずしも抽出速度を増大させるものではない ${ }^{48) 。 ~}$

捕集溶媒に何を用いるかが抽出効率に影響を与えると いう観点からの検討が行われている。van der Velde ${ }^{24)}$ は, 中一高沸点有機塩素系農薬およびPCB を対象にし た抽出の捕集溶媒をへキサンとイソオクタンで比較し, 沸点が中程度の物質に関しては後者の方が適することを 示した。へキサンは低沸点であるために捕集時の揮散損 失を生じやすく，それにともなって抽出対象物の損失も 生じることが原因と考えられる。ただ， $\mathrm{CO}_{2}$ の膨張にと もなう冷却効果があるので，筆者の経験からはとくに低 沸点でない限りあまり重要な因子ではないと考える。

液体溶媒ではなく，2.2で触れたように固相への捕集 も実施例があり, 確実な捕集と充填固相中をモディファ イヤーが流れることによる捕集試料のクリーンアップ効 果が期待できる59)。分析のためには再度抽出が必要に なるが, 興味ある方法である。

\section{7 抽出の最適化}

これまでに述べたように，抽出に影響する因子は機器 側のものだけでもいくつかあり，これに固体試料側の要 因が加わるといっそう複雑になる。どのような条件を適 用すれば定量的な抽出が可能になるかを合理的に決める ことが要求される。最適化を目的とした研究が数多くみ られるのも SFEの特徴である(7), 49),54),60),61)。これら の多くは, 压力, 温度, 時間, モディファイヤーなどの 因子を変化させて抽出を行い, 効率を比較するという手 法によっているが，それだけで最適化につなげるには困 難な点があると思われる。

最適化を戝るうえでは, 機器の操作条件という巨視的 な要因だけでなく，固体試料マトリックス上の活性点に おける被抽出物質と超臨界流体との相互作用 ${ }^{62)}$.63) に関 する微視的要因についても考慮する必要がある。

Hawthorne ${ }^{60)}$ によると, SFEには 3 つのステップが あり，それは1）マトリックスから流体への物質の効率 的な分配, 2 ) 試料谷器からの放出, 3 ) 効果的な捕集, であるという。この中で，1）についての機構の理解と 対処が重要である。本稿でこれまでに触れたように，従 来溶解度によって 1 ） の現象を説明するのが一般的であ るが, マトリックスと超臨界流体の間での物質の分配 性 $^{62)}$ ，およびマトリックスからの脱離性 ${ }^{63)}$ をげるこ とができる。この脱離性を重要視した研究例もあ

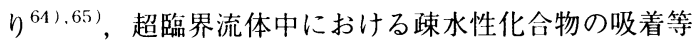
温線および脱離特性の測定を通して抽出における脱離過 程の重要性を強調している ${ }^{64)}$ ほか, 固体マトリックス と流体間での物質移動をモデル化することにより，実試 料からの污染物質の抽出機構を説明しようという試みが 行われている ${ }^{65)}$ 。現実の污染土壤など実試料でしばし ば期待される抽出効率が得られないことがSFEの欠点 
として指摘される ${ }^{65)}$ が, 多くの要因が複雑に絡み合っ ているためと推定される。また, 脱離に関連して, 排水 処理などに用いた活性炭の再生にSFEが適用されるこ とがあり，その際の吸着物質の脱離特性に関する検討も 行われている55).66).67)。

SFEでの抽出条件を選定するための指標を確立し, 具 体的に数值化することができれば, 最適化にとって有効 な手段になると思われる。このような趣旨に基づく検討 はまだ極く少数しか行われておらず68), 今後の研究が 望まれる。

目的物質と固体試料の組み合わせに対して, 抽出条件 を決める手順について, Hawthorne $ら^{60)}$ はFig.6に示す ような流れを提案している。最初の段階では, 目的物質 の極性, 固体マトリックスの水分含有量, 有機炭素含有 量, 無機分の組成および粒子サイズなどの性状および類 似物質の抽出に関する情報をもとに仮の条件を決める。 この条件が適切であるかどうかを見極めるために，不活 性な試料に対象物質のうち代表的なものを標準添加する ことにより予備抽出を行う。捕集と抽出に問題がなく走 量的な抽出が可能であれば抽出条件が一応確定される。 ただし，実試料における抽出効率は不活性試料としばし ば異なることからこのような場合，または予備抽出に よって期待された抽出効果が得られなければ，各条件を 再度検討することになる。なお，最初に設定する压力お よび温度条件は，適当な值がとくにわかっていなければ 300 400 atm, $50^{\circ} \mathrm{C}$ 程度を選択することになる。

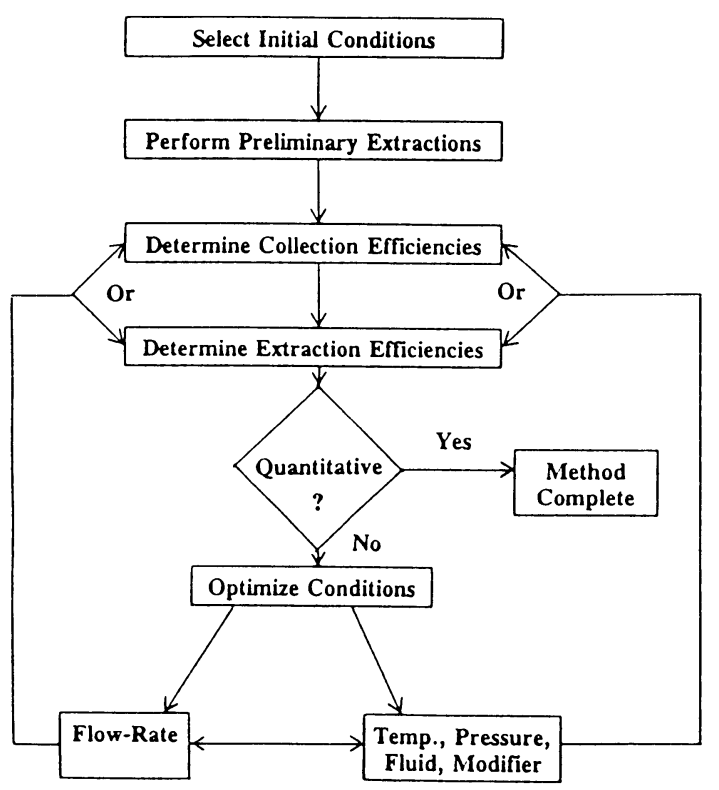

Fig. 6 Proposed interactive scheme for the development of quantitative SFE methods for complex environmental samples ${ }^{60)}$.

\section{8 SFEの精度}

従来の溶媒抽出法に対するSFEの測定精度に関する検 討も多く行われている7 7 ,24),31)。有機塩素系農薬および $\mathrm{PCB}$ 対象として,ソックスレー抽出法の相対標準偏 差が平均 $7.1 \%$ であるのに対し, SFEでは平均 $2.6 \%$ であ ると報告された例がある ${ }^{24)}$ 。

また，L.-Avila $ら^{69)}$ は，土壤中からのPAHの抽出を 例に異なる測定機関の間での精度を検討した。それによ ると, 試料中の濃度レベルによって精度が異なり, 濃度 が $1 \mathrm{mg} \cdot \mathrm{kg}^{-1}$ 以上であれば相対標準偏差は $27 \%$ 以下で あるが，逆に $1 \mathrm{mg} \cdot \mathrm{kg}^{-1}$ 以下だと $19 \sim 80 \%$ となり，ば らつきが大きくなる結果となった。微量濃度になれば, このような傾向はSFE 以外の抽出法でも現れると思わ れる。

\section{5. オンライン抽出としてのクロマトグラ フとの組み合わせ}

SFEは抽出を行うものであるとともに，選択的な溶出 機構が働くことから，抽出試料のクリーンアップをする ことになり, クロマトグラフとのオンライン化を可能に する。オンライン化すれば抽出捕集試料の取り扱いの手 間が省け，また対象物質の損失や污染を防ぐこともでき るし，抽出物の全量を導人できることから固体試料が少 量ですむという利点がある゙1。

オンライン的に結命されるクロマトグラフとしては, ガスクロマトグラフ (GC) と超臨界流体クロマトグラ フ（SFC）が主に用いられる。対象物質が熱的に安走で 揮発性であれば，SFE-GCの適用が適し，熱的に不安定 であれば, SFE-SFCの適用が考えられる。SFE-SFCでは, キャリヤー流体を同一にすることができ，インター フェースの仕組みは比較的単純でよい。

Table 5にオンラインSFEの研究例 ${ }^{70-75)}$ を示す。オン ライン化により，少量の試料を機器にセットすれば目的 物質の分離・分析さらにレポートまでが一連の流れで進 行することになる。これには問題になる点もないではな いが，環境分析の一つの方向を示すと考えてよいであろ う。Table $6^{1)}$ には, SFEのオフラインおよびオンライ ン適用と従来の溶媒抽出との比較例を示した。それぞれ の方法における溶媒使用量や所要時間に関する特徵がよ く現れている。

\section{6. おわりに}

SFE 利用した分析試料の調製方法は従来法にない多 くの利点をもち, 環境試料分析に関して, 将来の主要な 方法の一つになると思われる。その最大の利点は, 有機 溶媒の使用量を大幅に削減できることであり, 微量で有 害な化学物質の測定のためにはるかに多量の有機溶媒を 使用する矛盾を十分認識するならば，人間と環境に真に 
Table 5 Application examples of on-line coupling between SFE and chromatography

\begin{tabular}{|c|c|c|c|c|}
\hline $\begin{array}{l}\text { Tipe of on-line } \\
\text { coupling }\end{array}$ & Sample matrix & Analy te & Transfer technic to chromatograph & $\begin{array}{l}\text { Ref. } \\
\text { No. }\end{array}$ \\
\hline \multirow{4}{*}{ SFE-GC } & $\begin{array}{l}\text { Polyurethane } \quad \text { foam, } \\
\text { Cigarette smoke } \\
\text { particulate, Soil, Seeds } \\
\text { and berries }\end{array}$ & $\begin{array}{l}\text { Alkanes, Alkylben- } \\
\text { zenes, Naphtha- } \\
\text { lenes, PAH, } \\
\text { Aromatic alcohols }\end{array}$ & $\begin{array}{l}\text { Extraction cell outlet restrictor is directly inserted into } \\
\text { capillary G C column through on column injector. }\end{array}$ & 70 \\
\hline & $\begin{array}{l}\text { Sediment, Carbon black, } \\
\text { Crude oil source rocks }\end{array}$ & $\begin{array}{l}\text { Volatile halogenated } \\
\text { organics, PAH, } \\
\text { Alkanes }\end{array}$ & $\begin{array}{l}\text { Heated restrictor is directly Inserted into capillary GC } \\
\text { column and the oven is kept cool. }\end{array}$ & 71 \\
\hline & Grass & $\begin{array}{l}\text { Chlorpyrifos } \\
\text { insecticide }\end{array}$ & $\begin{array}{l}\text { Restrictor is connected to microcolumn LC and further } \\
\text { transfered to GC. }\end{array}$ & 72 \\
\hline & Sediment & PCB & $\begin{array}{l}\text { The extract is trapped at pre-column which is kept } \\
\text { cool and transfered to } G C \text { by rapid temperature ramp. }\end{array}$ & 73 \\
\hline \multirow{2}{*}{ SFE-SFC } & Polymer & Polyethylene & $\begin{array}{l}\text { Coupling device is used with 4-port and 6-port valve } \\
\text { between SFE and SFC. }\end{array}$ & 74 \\
\hline & $\begin{array}{l}\text { Poly(ethylene tere- } \\
\text { phthalate) film }\end{array}$ & Oligomers & & 75 \\
\hline
\end{tabular}

Table 6 Comparison of off-and on-line SFE with conventional techniques for the quantitation of PAHs in urban dust ${ }^{1)}$.

\begin{tabular}{|c|c|c|c|}
\hline Parameter & Conventional & Off-line SFE & On-line SFE \\
\hline Sample size & $1000 \mathrm{mg}$ & $20 \mathrm{mg}$ & $2 \mathrm{mg}$ \\
\hline Liquid solvent required & $450 \mathrm{ml}$ & $3 \mathrm{ml}$ & $0 \mathrm{ml}$ \\
\hline Extraction time & $48 h$ & $1 \mathrm{~h}$ & $15 \mathrm{~min}$ \\
\hline Extract concentration time & $3 \mathrm{~h}$ & $0-10 \mathrm{~min}$ & $0 \min$ \\
\hline $\begin{array}{l}\text { Analysis time for } \\
\text { extraction/concentration }\end{array}$ & $16 \mathrm{~h}$ & $20 \mathrm{~min}$ & $20 \mathrm{~min}$ \\
\hline $\begin{array}{l}\text { Shortest possible total } \\
\text { analysis time (one sample) }\end{array}$ & 3 days & $2 \mathrm{~h}$ & $1 \mathrm{~h}$ \\
\hline
\end{tabular}

やさしい分析方法を選択することが今後の環境分析のあ るべき姿ではないかと思われる。現在, 装置の価格や高 圧ガス関連の法制度上の問題などから，わが国ではまだ 広く用いられるという状況にはない。しかし, 欧米での 活発な研究状況をみると, わが国でもクリーン分析への 指向があることから，徐々に普及していく，あるいは他 の技法も含みながら進展していくのではないかと筆者は 考えている。

本稿が環境分析に携わる方々に多少とも参考になれば 幸いである。

\section{要約}

環境, 固体試料からの有機污染物質の抽出を, 有機溶 媒をほとんど用いることなくかつ短時間に行い得る手法 として注目されつつある超臨界流体抽出（SFE）法に関 する現状を整理した。欧米におけるSFE 法への注目, 適用性の検討は活発であり，クリーンな環境分析への意 識の高まりを示すものと思われる。SFE 法では, 装置の 操作条件が試料からの有機物の抽出能に大きな影響を与 えるので, 各条件がどのように影響するか, 最適な操作 
条件をどのように選定するかなどについて研究報告例を もとに整理し，今後の課題にも言及した。また，操作圧 力, 温度, モディファイヤーなどの条件設定の数值や内 容を具体的に整理し，実用上の用に供した。

\section{文 献}

1 ) Hawthorne, S. B.,: Analytical-scale supercritical fluid extraction. Anal. Chem., 62, 633A-642A (1990)

2 ) Snyder, J.,: Labs move to cleaner, safer extraction methods. Pollution engineering, No.15, 40-43 (1992)

3 ) Camel, V., Tambute, A., and Caude, M.,: Analyticalscale supercritical fluid extraction: a promising technique for the determination of pollutants in environmental matrices. J. Chromatogr., 642, 263-281 (1993)

4 ) Janda, V., Bartle, K. D., and Clifford, A. A.,: Supercritical fluid extraction in environmental analysis. ibid., 642, 283-299 (1993)

5 ) 平田幸夫：超臨界流体クロマトグラフィー, pp130-148, 「季刊化学総説 No.9 クロマトグラ フィーの新展開」, 日本化学会編, 学会出版センター, 東京 (1990)

6 ) Newman, A.,: What's new in analytical instruments: PITTCON'93. Environ. Sci. Technol., 27, 776-777 (1993)

7 ) L.-Avila, V., Young, R., Kim, R., and Beckert, W. F.,: Interlaboratory evaluation of an off-line supercritical fluid extraction/infrared spectrometric method for determination of petroleum hydrocarbons in solid matrixes. J. AOAC intern., 76, 555-564 (1993)

8 ) L.-Avila, V., Benedicto, J., Dodhiwala, N. S., Young, R., and Beckert, W. F., Development of an off-line SFE-IR method for petroleum hydrocarbons in soils. J. Chromatogr. Sci., 30, 335-343 (1992)

9 ) 文部省科学研究費重点領域研究, 超臨界流体の溶媒 特性の解明とその高度な工学的利用平成 5 年度研 究成果報告書 (1994)

10) Myer, L., Tehrani, J.,Thrall, C., and Gurkin, M.,: Supercritical fluid extraction (SFE): Advantages, applications and instrumentation for sample preparation. ISCO Applications Bulletin 69, 15-19 (1991)

11) 化学工学会編「化学工学便覧 (改訂 5 版)」, pp. 580, 丸善, 東京 (1988)

12）日本化学会編 改訂 4 版化学便覧 基礎編 II, pp. II -575- II-577，丸善，東京（1993）

13) Reid, R. C., Prausnitz, J. M., and Poling, B. E. (Ed.): The properties of gases \& liquids Fourth Ed., pp656-732, McGraw-hill, New York (1988)
14) Ong, C. P., Lee, H. K., and Li, S. F. Y.,: Chlorodifluoromethane as the mobile phase in supercritical fluid chromatography of selected phenols. Anal. Chem., 62, 1389-1391 (1990)

15) Hawthorne, S. B., Langenfeld, J. J., Miller, D. J., and Burford, M. D.,: Comparison of supercritical $\mathrm{CHCIF}_{2}$, $\mathrm{N}_{2} \mathrm{O}$, and $\mathrm{CO}_{2}$ for the extraction of polychlorinated biphenyls and polycyclic aromatic hydrocarbons. ibid., 64, 1614-1622 (1992)

16) Oostdyk, T. S., Grob, R. L., Snyder, J. L., and McNally, M. E.,: Study of sonication and supercritical fluid extraction of primary aromatic amines. ibid., 65, 596-600 (1993)

17) Hawthorne, S. B., Yang, Y., and Miller, D. J.,: Extraction of organic pollutants from environmental solids with sub-and supercritical water. ibid., 66 , 2912-2920 (1994)

18）篠田耕三：「第 3 版 溶液と溶解度 機能性溶液 - 組 織体溶液」, pp.76, 丸善, 東京 (1991)

19) Giddings, J. C., Myers, M. N., McLaren, L., and Keller, R. A.,: High pressure gas chromatography of nonvolatile species. Science, 162, 67-73 (1968)

20) Ashraf-Khorassani, M., Houck, R. K., and Levy, J. M.,: Cryogenically cooled adsorbent trap for off-line supercritical fluid extraction. J. Chromatogr. Sci., 30 , 361-366 (1992)

21) Porter, N. L., Rynaski, A. F., Campbell, E. R., Saunders, M., Richter, B. E., Swanson, J. T., Nielsen, R. B., and Murphy, B. J.,: Studies of linear restrictors and analyte collection via solvent trapping after supercritical fluid extraction. ibid., 30, 367-373 (1992)

22) Alexandrou, N., Miao, Z., Colquhoun, M., Pawliszyn, J. and Jennison, C.,: Supercritical fluid extraction and cleanup with capillary GC-ion trap mass spectrometry for determination of polychlorinated dibenzo- $p$-dioxins and dibenzofurans in environmental samples. ibid., 30, 351-357 (1992)

23) Larsen, B., and Facchetti, S.,: Use of supercritical fluid extraction in the analysis of polychlorinated dibenzodioxins and dibenzofurans. Fresenius J. Anal. Chem., 348, 159-162 (1994)

24) Van der Velde, E. G., de Haan, W., and Liem, A. K. D.,: Supercritical fluid extraction of polychlorinated biphenyls and pesticides from soil, Comparison with other extraction methods. J. Chromatogr., 626, 135-143 (1992)

25) Lee, H.-B., Peart, T. E., and Hong-You, R. L.,: In situ extraction and derivatization of pentachlorophenol 
and related compounds from soils using a supercri tical fluie extraction system. ibid., 605, 109-113 (1992)

26) Lopez-Avila, V., Dodhiwala, N. S., and Beckert, W F.,: Supercritical fluid extraction and its application to environmental analysis. J. Chromatogr. Sci., 28, 468-476 (1990)

27) Brooks, M. W., and Uden, P. C.,: Extraction and analysis of diesel fuel by supercritical fluid extrac tion and microbore supercritical fluid chromatogra phy. J. Chromatogr., 637, 175-179 (1993)

28) Griest, W. H., Ramsey, R. S., Ho, C.-H., and Caldwell, W. M.,: Supercritical fluid extraction of chemical warfare agent simulants from soil. ibid., 600 , 273-277 (1992)

29) Liu, Y., L.-Avila, V., Alcaraz, M., and Beckert, W. $\mathrm{F}$., Determination of organotin compounds in en vironmental samples by supercritical fluid extrac tion and gas chromatography with atomic emission detection. J. High Resolut. Chromatogr., 16, 106-112 (1993)

30) Janda, V., Steenbeke, G., and Sandra, P.,: Supercritical fluid extraction of s-triazine herbicides from sedi ment. J. Chromatogr., 479, 200-205 (1989)

$31)$ Snyder, J. L., Grob, R. L., McNally, M. E., and Oostdyk, T. S.,: Comparison of supercritical fluid extrac tion with classical sonication and soxhlet extractions for selected pesticides. Anal Chem., 64, 1940-1946 (1992)

32) Paschke, T., Hawthorne, S. B., Miller, D. J., and Wenclawiak, B.,: Supercritical fluid extraction of nitrated polycyclic aromatic hydrocarbons and polycy. clic aromatic hydrocarbons from diesel exhaust par ticulate matter. J. Chromatogr., 609, 333-340 (1992)

33) Alexandrou, N., and Pawliszyn, J.,: Supercritical fluid extraction for the rapid determination of polychlorinated dibenzo-p-dioxins and dibenzofurans in municipal incinerator fly ash. Anal. Chem., 61, 2770-2776 (1989)

34）川本克也：超臨界流体抽出法による模擬廃棄物試料 中有機塩素化合物の抽出特性と実試料への適用，廃 棄物学会論文誌, 投稿中

35) Field, J. A., Miller, D. J., Field, T. M., Hawthorne, S. B., and Giger, W.,: Quantitative determination of sulfonated aliphatic and aromatic surfactants in sewage sludge by ion-pair/supercritical fluid extraction and derivatization gas chromatography/mass spectrometry. Anal. Chem., 64, 3161-3167 (1992)
36) Hale, R. C., and Gaylor, M. O.,: Determination of PCBs in fish tisues using supercritical fluid extraction. Environ. Sci. Technol., 29, 1043-1047 (1995)

37 ) Bicking, M. K. L., Hayes, T. G., Kiley, J. C., and Deming, S. N.,: An experimental design approach to the optimization of supercritical fluid extraction for the determination of oil and grease in soil. J. Chromatogr. Sci., 31, 170-176 (1993)

38) Eckert-Tilotta, S. E., Hawthorne, S. B., and, Miller, D. J.,: Supercritical fluid extraction with carbon dioxide for the determination of total petroleum hydrocarbons in soil. Fuel, 72, 1015-1023 (1993)

39) Hawthorne, S. B., Krieger, M. S., and Miller, D. J.,: Supercritical carbon dioxide extraction of polychlorinated biphenyls, polycyclic aromatic hydrocarbons, heteroatom-containing polycyclic aromatic hydrocarbons, and $n$-alkanes from polyurethane foam sorbents. Anal. Chrm., 61, 736-740 (1989)

40) Lohleit, M., Hillmann, R., and Bachmann, K.,: The use of supercritical-fluid extraction in environmental anaysis. Fresenius J Anal Chem., 339, 470-474 (1991)

41) Wong, J. M., Kado, N. Y., Kuzmicky, P. A., Ning, H.S., Woodrow, J. E., Hsieh, D. P. H., and Seiber, J. N.,: Determination of volatile and semivolatile mutagens in air using solid adsorbents and supercritical fluid extraction. Anal. Chem., 63, 1644-1650 (1991)

42) Ezzell, J. L., and Richter, B. E.,: Supercritical fluid extraction of pesticides and phthalate esters following solid phase extraction from water. J. Microcol. Sep., 4, 319-323 (1992)

43) Howard, A. L., and Taylor, L. T.,: Quantitative supercritical fluid extraction of sulfonyl urea herbicides from aqueous matrices via solid phase extraction disks. J. Chromatogr. Sci., 30, 374-382 (1992)

44）川本克也, 岩崎重雄：ディスク型固相抽出剤と超臨 界流体抽出法を用いた水中農薬の濃縮と抽出，第29 回日本水環境学会年会講演集, 204（1995）

45) Hedrick, J., and Taylor, L. T,.: Quantitative supercritical fluid extraction/supercritical fluid chromatography of a phosphonate from aqueous media. Anal. Chem., 61, 1986-1988 (1989)

46) Ghonasgi, D., Gupta, S., Dooley, K. M., and Knopf, F. C.,: Supercritical $\mathrm{CO}_{2}$ extraction of organic contaminants from aqueous streams. AIChE Jourmal, 37, 944-950 (1991)

47) Ho, J. S., and Tang,P.H.,: Optimization of supercritical fluid extraction of environmental pollutants from 
a liquid-solid extraction. J. Chromatogr. Sci., 30, 344-350 (1992)

48) Snyder, J. L., Grob, R. L., McNally, M. E., and Oostdyk, T.S.,: The effect of instrumental parameters and soil matrix on the recovery of organochlorine and organophosphate pesticides from soils using supercritical fluid extraction. ibid., 31, 183-191 (1993)

49) Reindl, S., and Hofler, F.,: Optimization of the parameters in supercritical fluid extraction of polynuc lear aromatic hydrocarbons from soil samples. Anal. Chem., 66, 1808-1816 (1994)

50) Robertson, A. M., and Lester, J. N.,: Supercritical fluid extraction of s-triazines and phenylurea herbicides from sediment. Environ. Sci. Technol., 28, 346-351 (1994)

51) Langenfeld, J. J., Hawthorne, S. B., Miller, D. J., and Pawliszyn, J.,: Effects of temperature and pressure on supercritical fluid extraction efficiencies of polycyclic aromatic hydrocarbons and polychlorin ated biphenyols. Anal. Chem., 65, 338-344 (1993)

52) Dooly, K. M., Ghonasgi, D., Knopf, F. C., and Gambrell, R. P.,: Supercritical $\mathrm{CO}_{2}$-cosolvent extraction of contaminated soils and sediments. Environmental Progress, 9, 197-203 (1990)

53) Liu, M. H., Kapila, S., Yanders, A. F., Cleveger, T. E., and Elseewi, A. A.,: Role of entrainers in supercritical fluid extraction of chlorinated aromatics from soils. Chemosphere, 23，1085-1095 (1991)

54) Wheeler, J. R., and McNally, M. E.,: Supercritical fluid extraction and chromatography of representative agricultural products with capillary and microbore columns. J. Chromatogr. Sci., 27, 534-539 (1989)

55) Robertson, A. M., and Lester, J. N.,: Recovery of striazine herbicides and associated breakdown products from granular activated carbon using supercritical fluid extraction. Wat. Environ. Res., 67, 899-905 (1995)

56) Lee, H. B., Peart, T. E., Hong-You, R. L., and Gere, D. $\mathrm{R}$.,: Supercritical carbon dioxide extraction of polycyclic aromatic hydrocarbons from sediments. $J$. Chromatogr. A, 653, 83-91 (1993)

57 ) Langenfeld, J. J., Hawthorne, S. B., Miller, D. J., and Pawllszyn, J.,: Role of modifiers for analytical-scale supercritical fluid extraction of environmental samples. Anal. Chem., 66, 909-916 (1994)

58) Fahmy, T. M., Paulaitis, M. E., Johnson, D. M., and McNally, M. E. P.,: Modifier effects in the supercri- tical fluid extraction of solutes from clay, soil, and plant materials. ibid., 65, 1462-1469 (1993)

59) Bowadt, S., Johansson, B., Pelusio, F., Larsen, B. R., and Rovida,C.,: Solid-phase trapping of polychlorinated biphenyls in supercritical fluid extraction. $J$. Chromatogr. A, 662, 424-433 (1994)

60) Hawthorne, S. B., Miller, D. J., Buford, M. D., Langenfeld, J. J., E.-Tilotta, S., and Louie, P. K.,: Factors controlling quantitative supercritical fluid extraction of environmental samples. J. Chromatogr., 642, 301-317 (1993)

61) Furton, K. G., and Lin, Q.,: Variation in the supercritical fluid extraction of polychlorinated biphenyls as a function of sorbent type, extraction cell dimensions, and fluid flow rate. J. Chromatogr. Sci., 31. 201-206 (1993)

62) Hills, J. W., and Hill, Jr., H. H.,: Simultaneous supercritical fluid derivatization and extraction. Anal. Chem., 63, 2152-2155 (1991)

63) David, F., Verschuere, M., and Sandra, P.,: Off-line supercritical fluid extraction-capillary GC applications in environmental analysis. Fresenius J. Anal. Chem., 344, 479-485 (1992)

64) Earkey, C., Madras, G., Orejuela, M., and Akgerman, A.,: Supercritical carbon dioxide extraction of organics from soil. Envirom. Sci. Technol., 27, 1225-1231 (1993)

65) Langenfeld, J. J., Hawthorne, S. B., Miller, D. J., and Pawliszyn, J.,: Kinetic study of supercritical fluid extraction of organic contaminants from heterogeneous environmental samples with carbon dioxide and elevated temperatures. Anal. Chem., 67, 1727-1736 (1995)

66）中井敏博, 佐藤芳夫, 高橋信行, 加藤義重：ニトロ ベンゼンを吸着させた活性炭の超臨界流体二酸化炭 素による再生, 日本化学会誌, 1992, 1374-1379 (1992)

67）中井敏博，佐藤芳夫，高橋信行，加藤義重：芳香族 ニトロ化合物吸着活性炭の再生に及ぼす置換基の影 響, 日本化学会誌, 1993，199-204（1993）

68）川本克也：廃棄物中有機化合物の超臨界流体抽出特 性と抽出条件の選定, 廃棄物学会第 6 回研究発表会 講演論文集，738-740（1995）

69) Lopez-Avila, V., Young, R., Tehrani, J., Damian, J., Hawthorne, S., Dankers, J., and vander Heiden, C.,: Mini-round-robin study of a supercritical fluid extraction method for polynuclear aromatic hydrocarbons in soils with dichloromethane as a static modi- 
fier. J. Chromatogr. A, 672, 167-175 (1994)

70) Hawthorne, S. B., Miller, D. J., and Krieger, M. S.,: Rapid and quantitative extraction and analysis of trace organics using directly coupled SFE-GC. $J$. High resolut. chromat., 12, 714-720 (1989)

71) Levy, J. M., and Rosselli, A. C.,: Quantitative supercritical fluid extraction coupled to capillary gas chromatography. Chromatographia, 28, 613-616 (1989)

72) Cortes, H. J., Green, L. S., and Campbell, R. M.,: Online coupling of supercritical fluid extraction with multidimensional microcolumn liquid chromatogra phy/gas chromatography. Anal. Chem., 63, 2719-2724 (1991)
73) Onuska, F. L., and Terry, K. A.,: Supercritical fluid extraction of PCBs in tandem with high resolution gas chromatography in environmental analysis. $J$. High resolut. chromat., 12, 527-531 (1989)

74) Engelhardt, H., Zapp, J., and Kolla, P.,: Sample preparation by supercritical fluid extraction in environmental food and polymer analysis. Chromatographia, 32, 527-537 (1991)

75) Bartle, K. D., Boddington, T., Clifford, A. A., Cotton, N. J., and Dowle, C.J.,: Supercritical fluid extraction and chromatography for the determination of oligomers in poly (ethylene terephthalate) films. Anal. Chem., 63, 2371-2377 (1991) 